\title{
BUDAYA SUMANG DAN IMPLEMENTASINYA TERHADAP RESTORASI KARAKTER MASYARAKAT GAYO DI ACEH
}

\author{
Syukri \\ Pascasarjana UIN Sumatera Utara \\ Jl. IAIN No.1 Medan, Sumatera Utara, 20232 \\ e.mail: syukriur@yaho.com
}

\begin{abstract}
Abstrak: Tulisan ini berupaya memahami sistem budaya masyarakat Gayo yang populer dengan sumang yang berarti tindakan menyimpang dari konvensi tata krama dan bertentangan dengan Islam dan adat. Sistem budaya sumang Gayo ini bermuatan pengetahuan, keyakinan, nilai, aturan, dan hukum yang menjadi acuan bagi tingkah laku dalam kehidupan masyarakat Gayo. Implementasi budaya sumang terhadap restorasi karakter masyarakat Gayo sangat relevan, karena bernilai spiritual dan berorientasi kepada akhlâq al-karîmah, menjaga harga diri, harkat, martabat keluarga dan masyarakat. Harga diri disebut mukemel artinya punya rasa malu. Kalau masyarakat Gayo tidak berkarakter berarti tidak punya rasa malu (gere mukemel). Penulis menyimpulkan bahwa budaya sumang berperan penting dalam merestorasi kultur masyarakat menjadi lebih berkarakter mulia ketika diterapkan secara utuh dalam kehidupan masyarakat.
\end{abstract}

\begin{abstract}
Sumang Tradition and Its Implementation on Character Restoration of Aceh Gayo Society. This paper seeks to understand the cultural system of Gayo society that is popular with Sumang that means acts deviate from convention of manners and contrary to Islam and adat. This Gayo sumang culture system is filled with knowledge, beliefs, values, rules, and laws that become the reference for behavior in Gayo social life. The Implementation of sumang culture towards restoration of Gayo community character is very relevant, because it is spiritual and oriented to morality al-karimah, maintaining self-esteem, family and social dignity. Self-esteem called mukemel means "have a sense of shame". The author concludes that sumang culture plays an important role in restoring the culture of society to be more noble character when applied in the whole life of the community.
\end{abstract}

Kata Kunci: budaya sumang, Aceh, Gayo, budaya, karakter 


\section{Pendahuluan}

Masyarakat Gayo merupakan bagian integral bangsa Indonesia. Mereka memiliki karakter dan budaya yang spesifik sebagaimana masyarakat Indonesia umumnya. Di antara budayanya adalah sumang yang merupakan sistem budaya yang telah berakar dalam masyarakat Gayo sebagai pola dasar dan landasan hidup, baik dalam pergaulan, kekerabatan, sosial kemasyarakatan, maupun pengetahuan, keyakinan, nilai, dan aturan yang menjadi acuan tingkah laku dalam kehidupan masyarakat. ${ }^{1}$ Budaya sumang dapat menentukan hukum atau nilai dari suatu perbuatan yang dilakukan untuk ditentukan baik buruknya dan menghendaki terciptanya masyarakat berakhlak, ${ }^{2}$ berkarakter, beretika, aman, damai dan sejahtera lahiriah dan batiniah. Budaya sumang menjadi ukuran nilai apakah seseorang berperilaku tertib atau tidak dalam kehidupan sosial masyarakat Gayo di Aceh.

Budaya sumang bernilai baik dan buruk, benar dan salah, amar makruf nahi mungkar. Karena itu, budaya sumang merupakan suatu sistem budaya Gayo yang bernilai spiritual dan berorientasi kepada akhlak mulia, membentuk pergaulan hidup bersama yang berlandaskan ajaran Islam dan adat-istiadat. ${ }^{3}$ Jadi, budaya sumang menjadi suatu tradisi masyarakat Gayo secara turun temurun dari generasi kepada generasi selanjutnya secara estafet, sebagaimana C. Snouck Hurgronje dalam bukunya Het Gajoland en Zijne Bewoners menuliskan bahwa budaya sumang dan adat-istiadat masyarakat Gayo adalah hasil pengalamanpengalaman hidup dari masalah-masalah yang dihadapi, dari tata cara yang ditemui, yang pada akhirnya dijadikan suatu ketetapan hukum yang terus hidup dari generasi ke generasi. ${ }^{4}$

Budaya sumang Gayo sebagai suatu sistem dari budaya Indonesia akan dapat memberikan kontribusi yang sangat berarti bagi etika pembangunan kebudayaan nasional, sekaligus dalam pentas pemikiran politik Islam kontemporer di Indonesia. ${ }^{5}$ Namun terbatasnya literaturliteratur ilmiah mengenai masyarakat Gayo dan kebudayaannya, termasuk budaya sumang ini, membuat ini kurang dikenal secara luas oleh masyarakat Indonesia khususnya, dan

${ }^{1}$ M. Junus Melalatoa, "Budaya Malu: Sistem Budaya Gayo" dalam Sistem Budaya Indonesia (Jakarta: Universitas Indonesia-Pelajar Jakarta, 1997), h. 202.

${ }^{2}$ Akhlak berasal dari kata Arab, yaitu isim mashdar (bentuk infinitif) dari kata akhlâqa, yukhliqu, ikhlâqan, sesuai dengan timbangan (wazan) tsulasi majid yang berarti al-sajiyah (perangai), al-thabi'ah (tabiat) al-'âdat (kebiasaan, kelaziman), al-marû'ah (peradaban yang baik). Lihat. Jamil Shaliba, al-Mújam al-Falsafi, Juz I (Mesir: Dâr al-Kitâb al-Mishri, 1978), h. 539. Lihat pula Luis Ma'luf, Kamus al-Munjid (Beirut: al-Maktabah al-Katulikiyah, t.t.), h. 194.

${ }^{3}$ Lihat Syukri, Sarakopat: Sistem Pemerintahan Tanah Gayo dan Relevansinya terhadap Pelaksanaan Otonomi Daerah (Jakarta: Penerbit Hijri Utama, 2006), h. 32.

${ }^{4}$ Lebih lanjut dapat merujuk kepada, Hatta Aman Asnah, Gayo: Masyarakat dan Kebudayaan Awal Abad ke-20 (Jakarta: Balai Pustaka, 1996), h. 70-71.

${ }^{5}$ Pergulatan perjuangan politik umat Islam di Indonesia tidak pernah sepi untuk dibahas. Denyutnya masih terasa hingga kini, ketika reformasi menderu ke seantero negeri yang tidak bisa dilupakan. Pengorbanan mereka berhulu dari tetesan ke hilir saat Piagam Jakarta dihapuskan. Lihat Dhurorudin Mashad, Akar Konflik Politik Islam di Indonesia (Jakarta: Pustaka al-Kautsar, 2008). 
di mata dunia internasional umumnya. Berdasarkan permasalahan itulah, tulisan ini menjadi urgen dan berusaha menggali tentang masyarakat Gayo dan kebudayaannya, khususnya mengenai budaya sumang yang kemudian dihubungkan dengan restorasi karakter masyarakat Gayo di Aceh dewasa ini.

Tanpa bergumul dan bersentuhan sama sekali dengan persoalan kontemporer, budaya sumang Gayo ini akan menjadi punah atau ketinggalan (out of date), bahkan tidak bermanfaat (obselete) ${ }^{6}$ A.R. Hakim Aman Pinan mengatakan bahwa adat dan budaya sumang itu dipergunakan sudah terlalu jauh menyimpang dari aturan-aturan yang sebenarnya, sehingga warnanya sudah tidak orisinal lagi, dan perkembangannya memudar terus, seakan-akan adat itu tidak mempunyai roh lagi. ${ }^{7}$ Karena itu, tujuan tulisan ini adalah untuk mengetahui latar munculnya sistem budaya sumang kemudian menemukan relevansinya dengan restorasi karakter mayarakat Gayo dewasa ini. Sedangkan manfaatnya adalah untuk memberikan kontribusi bagi pemerintah daerah, tokoh agama (ulama), tokoh adat, cendekiawan dan masyarakat dalam menata dan melestarikan budaya sumang Gayo yang adilihung ini agar tetap orisinal dan perkembangannya tidak memudar seiring dengan kemajuan ilmu pengetahuan dan teknologi, globalisasi, dan modernisasi bangsa.

Penelusuran terhadap literatur kepustakaan, ditemukan bahwa belum ada tulisan yang membahas tentang budaya sumang dan relevansinya dengan restorasi karakter masyarakat Gayo. Karena itu, tulisan ini dipandang penting, baru dan aktual. Penting karena dapat dijadikan sebagai salah satu referensi ilmiah bagi para pengkaji dan pemerhati tentang budaya sumang masyarakat Gayo. Di katakan baru, karena tulisan ini baru pertama kali dilakukan, belum pernah ditulis dan diteliti oleh para ahli dan pakar. Kalaupun ada masih bersifat teoretis deskriptif saja, belum menyentuh dengan restorasi karakter masyarakat Gayo dewasa ini. Sementara tulisan ini bersifat praktis dengan melihat kondisi objektif dan fair di lapangan, melalui para informan ahli dan dokumen yang otentik dan orisinal. Dikatakan aktual, karena masalah adat dan budaya sumang tetap dipelihara, dilestarikan dan tetap hangat diperbincangan serta didialogkan oleh masyarakat Gayo sepanjang sejarah di Tanah Gayo Aceh.

\section{Metode Penelitian}

Mengacu dari fokus permasalahan yang diajukan, maka tulisan ini menggunakan

${ }^{6}$ Menurut M. Amin Abdullah bahwa jika diskursus kalam dan falsafah Islam tanpa bergumul dan bersentuhan sama sekali dengan persoalan kontemporer, maka pemikiran Islam itu akan menjadi ketinggalan (out of date) atau bahkan tidak bermanfaat (obselete). M. Amin Abdullah, Falsafah Kalam di Era Post Modernisme (Yogyakarta: Pustaka Pelajar, 1995), h. 90; lihat juga Mhd. Syahnan dan Saleh Partaonan Daulay, "Reconsidering the Convergence of the Philosophy of Islamic Law with Other Scinces," dalam Indo-Islamica: Journal of Islamic Science, Vol. 3, No. 1 (2006).

${ }^{7}$ Baca, A.R. Hakim Aman Pinan, "Peranan Adat Gayo dalam Masa Peralihan," dalam Majalah Telangke, Edisi Nomor: 3 Tahun 1/Maret/1996, h. 12. 
metode penelitian kualitatif ${ }^{8}$ yang bertujuan untuk mendapatkan suatu gambaran yang mendalam tentang budaya sumang dan implementasinya terhadap restorasi karakter masyarakat Gayo di Aceh. Dengan demikian, jenis penelitian ini adalah penelitian kualitatif dengan menitikberatkan pada pemahaman terhadap proyek yang diteliti dengan menggunakan field research dan frame of reference. Sumber data penelitian ini terdiri atas sumber primer dan sekunder. Sumber primer berasal dari jawaban informan dengan melakukan wawancara mendalam (depth interview), yaitu narasumber yang memiliki otoritas menjawab tentang budaya sumang dan implemantasinya terhadap restorasi karakter masyarakat Gayo di Aceh. Adapun sumber sekunder penelitian ini adalah informasi-informasi yang diperoleh dari kantor pemerintah daerah dan Lembaga Adat Gayo.

Di samping itu, teknik pengumpulan data yang digunakan dalam penelitian ini adalah pengumpulan data studi kepustakaan (library research) dengan cara mengumpulkan dan memeriksa dokumen-dokumen yang memberikan informasi yang dibutuhkan oleh peneliti. ${ }^{9}$ Data yang ada dalam kepustakaan dikumpulkan dan diolah dengan cara editing, coding, tabulating, organizing, dan penemuan hasil penelitian, sehingga data dan pengkajiannya diarahkan untuk menemukan kedudukan, kekuatan makna, dan keterkaitan antar dokumen. ${ }^{10}$

Kerangka pemikiran yang dibangun dalam penelitian ini berisi tentang sistem budaya sumang, kemudian dihubungkan dengan restorasi karakter masyarakat Gayo. Upaya menghubungkan diperlukan kerangka pemikiran yang sistematis, dan universal, agar mudah diketahui, dipahami, kemudian dapat diimplementasikan secara menyeluruh ( $k a f f a h$ ) dalam berbagai aspek hidup, dan kehidupan sehari-hari, baik di rumah, sekolah dan di masyarakat. Lebih jelas lihat kerangka pikirini:

${ }^{8}$ Kehadiran penelitian kualitatif berkaitan erat dengan sifat unik dari realitas sosial dan dunia tingkah laku manusia sendiri. Keunikannya bersumber dari hakikat manusia sebagai makhluk psikis, sosial, dan budaya yang mengaitkan makna dan interpretasi itu sendiri dipengaruhi oleh lingkungan sosial dan budaya. Sanafiah Faisal, Penelitian Kualitatif: Dasar-Dasar dan Aplikasi (Malang: IKIP Malang Press, 1990), h. 2.

${ }^{9}$ Untuk lebih jelas dapat merujuk kepada M. Syamsuddin, Operasionalisasi Penelitian Hukum (Jakarta: RajaGrafindo Persada, 2007), h. 99.

${ }^{10}$ Baca, Asep Saepul Hamdi dan E. Bahruddin, Metode Penelitian Kuantitatif Aplikasi dalam Pendidikan (Yogyakarta: Depublish, 2014), h. 12-13. 


\section{SKEMA KERANGKA PIKIR}

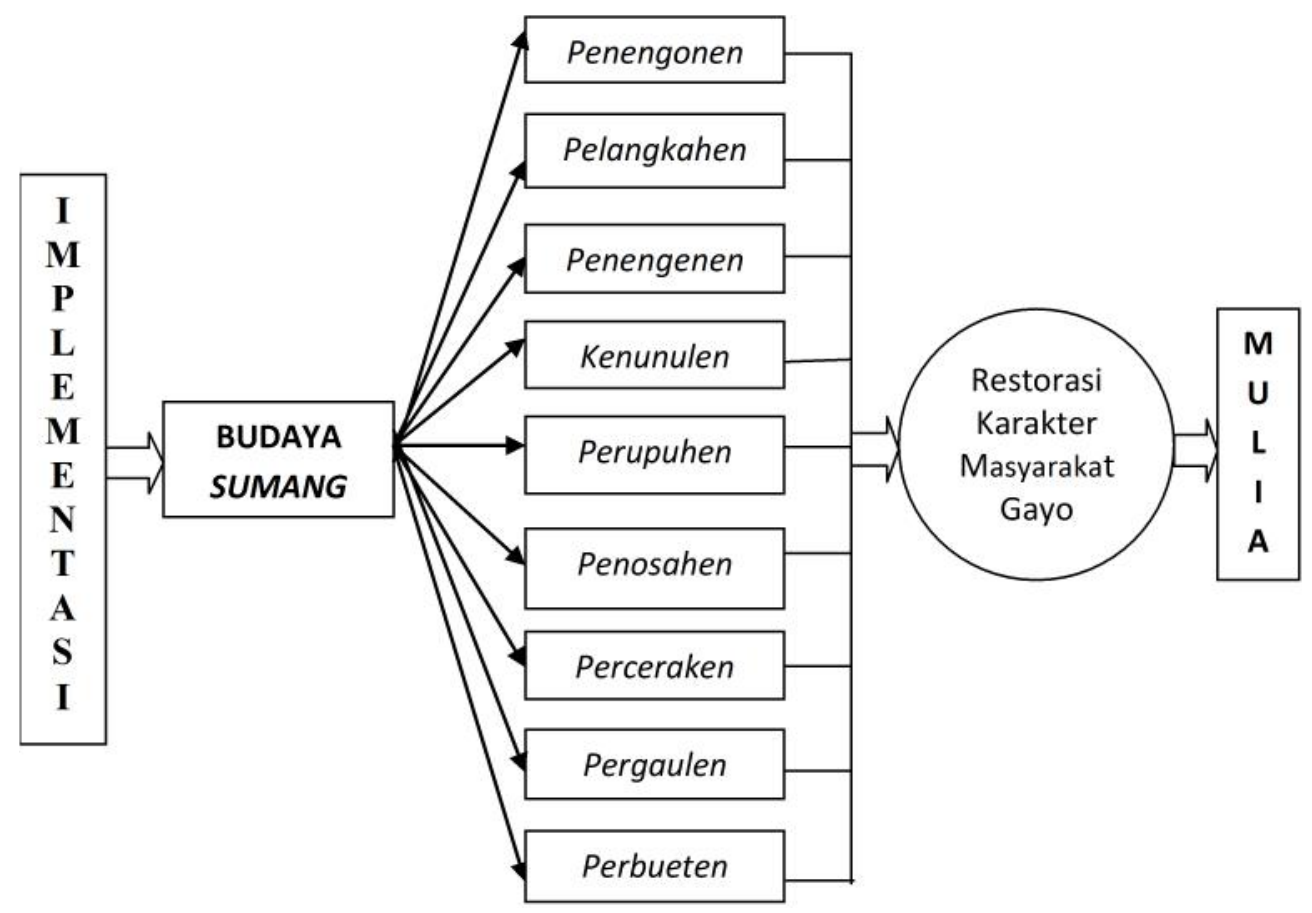

Kerangka pikir di atas menunjukkan bahwa implementasi budaya sumang terhadap restorasi karakter masyarakat Gayo di Aceh sangat signifikan. Karena dalam kajian sistem budaya Sumang Opat (Sumbang Empat) yaitu sumang penengonen (Sumbang Penglihatan), Sumang Pelangkahen (Sumbang Perjalanan), Sumang Penengenen(Sumbang Pendengaran) danSumang Kenunulen (Sumbang Duduk), ditambah lagi budaya sumang-sumang yang lain seperti Sumang Perupuhen (Sumbang Berpakaian), Sumang Penosahen (Sumang Pemberian), Sumang Perceraken (Sumbang Perkataan), Sumang Pergaulen (Sumbang Pergaulan) dan Sumang Perbueten (Sumbang Perbuatan), semuanya model atau bentuk budaya Sumang sebagaimana terlihat dalam skema kerangka pemikiran di atas, sangat berkaitan terhadap pembinaan restorasi karakter masyarakat Gayo menuju kepada kepribadian yang mulia, terpuji, berharkat dan bermartabat.

\section{Hasil dan Pembahasan Makna Budaya Sumang Masyarakat Gayo}

Budaya sumang dalam masyarakat Gayo di Aceh terdiri atas dua kata yaitu budaya dan sumang. Budaya ${ }^{11}$ atau culture adalah segala usaha dan aktivitas manusia dalam mengelola

${ }^{11}$ Budaya sering juga disebut dengan tradisi. Tradisi diartikan sebagai ide umum, sikap dan kebiasaan dari masyarakat yang tampak dari perilaku sehari-hari yang menjadi kebiasaan dari 
dan mengubah alam. Sedangkan budaya Gayo adalah setiap atau segala usaha dan tradisi masyarakat Gayo yang tampak dari perilaku sehari-hari yang menjadi kebiasaan dalam kehidupan masyarakat Gayo yang bermuatan pengetahuan, keyakinan (beliefs), nilai (values), norma-norma. Semuanya dinyatakan sebagai edet (adat), dan ditambah hasil kebiasaan yang tidak mengikat yang disebut resam, yaitu apa yang dilakukan menurut aturan yang biasa berlaku (peraturen), adat-istiadat. ${ }^{12}$ Karena itu, budaya masyarakat Gayo merupakan faktor yang penting dalam membentuk pola hidup masyarakat Gayo untuk menjadi lebih maju, optimis, berani bersikap, bertindak, dan berperilaku kooperatif.

Budaya masyarakat Gayo merupakan suatu cara hidup yang berkembang dan dimiliki bersama oleh masyarakat Gayo dan diwariskan secara turun-temurun dari generasi ke generasi. Budaya Gayo disebut juga tradisi, ${ }^{13}$ hukum adat, ${ }^{14}$ kebiasaan-kebiasaan ${ }^{15}$ dan adat istiadat. Dalam praktiknya, istilah adat istiadat mengandung arti luas, mencakup semua hal di mana suatu masyarakat atau seseorang menjadi terbiasa untuk dapat melakukannya. ${ }^{16}$ Karena itu, adat istiadat Gayo merupakan aturan yang bersendikan syariat Islam yang lazim dituruti, dihormati, dimuliakan sejak dahulu dan dijadikan sebagai landasan hidup.

Sedangkan makna sumang adalah istilah yang berasal dari bahasa asli daerah Tanah Gayo. Kata sumang mengandung arti perbuatan amoral yang dilakukan oleh seorang lakilaki dan perempuan yang telah dewasa yang amat dilarang menurut adat. Sumang mengandung arti, sumbang yaitu hal-hal yang amat dilarang atau tidak sopan. Budaya sumang adalah suatu model budaya yang integral antara akal pikiran, hati, rohani dan jasmaninya, akhlak, sikap, tabiat, dan keterampilan serta keahliannya, menyiapkan masyarakat untuk hidup dalam keadaan aman, damai, bahagia, sejahtera dunia dan akhirat. ${ }^{17}$ Budaya sumang berupaya

kelompok dalam masyarakat tersebut. Lihat Soekarto Indra Fachrudi, Bagaimana Mangakrabkan Sekolah dengan Orang Tua Murid dan Masyarakat (Malang: IKIP Malang, 1994), h. 20.

${ }^{12}$ Lihat, M. J. Melalatoa, et al. Kamus Bahasa Gayo Indonesia (Jakarta: Pusat Pembinaan dan Pengembangan Bahasa Departemen Pendidikan dan Kebudayaan, 1985), h. 295-296.

${ }^{13}$ Tradisi [Inggris: tradition, dan Latin: tradition, dari tradire (menyerahkan)]. Lihat, Loren Bagus, Kamus Filsafat (Jakarta: Gramadia Pustaka Utama, 1996), h. 1115.

${ }^{14} \mathrm{Hukum}$ adat adalah hukum adat Gayo yang hidup dan berkembang dalam masyarakat Gayo. Lihat, Himpunan Qanun Kabupaten Aceh Tengah (Takengon: Sekda, 2002), h. 143.

${ }^{15}$ Kebiasaan-kebiasaan adalah suatu kegiatan atau perbuatan yang pada dasarnya tidak bersumber dari hukum adat atau adat-istiadat, akan tetapi telah diakui oleh umum dan telah dilaksanakan berulang-ulang dan terus menerus. Lihat, Ibid., h. 143.

${ }^{16}$ Pengertian adat istiadat lebih jelas dapat merujuk kepada H.A.R. Gibb dan J. H. Kramers (ed.), Shorter Encyclopaedia of Islam (Leiden: E.J. Brill, 1961), h. 14-15.

${ }^{17}$ Makna budaya sumang di atas sangat selaras dengan pengertian pendidikan Islam menurut Yûsuf al-Qardhâwi bahwa pendidikan Islam adalah pendidikan manusia seutuhnya; akal dan hatinya, rohani dan jasmaninya, akhlak dan keterampilannya. Karena itu, pendidikan Islam adalah menyiapkan manusia untuk hidup baik dalam keadaan damai maupun perang, dan menyiapkannya untuk menghagai masyarakat dengan segala kebaikan dan kejahatannya, manis dan pahitnya. Yûsuf al-Qardhâwî, Pendidikan Islam dan Madrasah Hasan al-Banna, terj. H. Bustami A. Gani dan Zainal Abidin Ahmad (Jakarta: Bulan Bintang, 1990), h. 157. 
menghindari perbuatan yang menyimpang dari konvensi-konvensi tata krama yang berlaku dalam masyarakat, selain bertentangan dengan adat juga dari segi moralitas, tindakan atau perbuatan itu sangat tidak terpuji. ${ }^{18}$

Dalam masyarakat Gayo, budaya sumang merupakan suatu model pendidikan, yaitu sebagai pola dasar landasan hidup dalam bermasyarakat. Karenanya apabila ada seseorang bertindak di luar pola pendidikan yang bersifat normatif akan ditolak dan dilarang, seperti dalam adat Gayo Nge lengkap edet urum ukum, nge lengkap sarakopat sagi pendari (sudah lengkap adat dan hukum, sudah lengkap dengan semua perangkatannya, mulai dari atas sampai bawahan). ${ }^{19}$ Munculnya budaya sumang bertitik awal dari sikap mendidik dan membina manusianya menjadi manusia yang paripurna (insan kamil), ${ }^{20}$ yaitu terkumpulnya seluruh potensi intelektual, rohani, dan fisik yang ada pada diri manusia. Secara kronologis, ada empat sumang dalam adat Gayo yang disebut sumang opat. Penjabaran dari empat sumang ini melahirkan sumang-sumang yang lain:

\section{Sumang Penengonen (Sumbang Penglihatan)}

Sumang Penengonen (sumbang penglihatan) disebut juga dengan Sumang Penerahen yaitu memandang wanita dengan iktikad yang tidak baik. Artinya sangat merasa malu kalau seorang pria melihat seorang wanita dengan pandangan hawa nafsu. Sebaliknya malu apabila seorang wanita memandang laki-laki yang bukan mahramnya dengan pandangan tajam menimbulkan birahinya. Ibn Qayyim al-Jauziyah mengatakan "siapa yang mengumbar pandangannya akan menuai akibatnya. Siapa berlama-lama memandang, penyelesaiannya akan terus berkelanjutan, hilang waktunya, dan berkepanjangan deritanya"21 Jadi, Sumang Penengonen mengontrol mata dan hati dari pandangan yang tercela, karena hal itu tabu atau pantang dilakukan. ${ }^{22}$ Untuk menahan diri dari pandangan yang menjurus kepada nafsu seksual perlu ditanamkan tauhid ${ }^{23}$ dan tazkiyah al-anfus. ${ }^{24}$

\footnotetext{
${ }^{18}$ Lebih jelas dapat merujuk kepada A.R. Hakim Aman Pinan, "Budaya Sumang yang Menjadi Sumbang," Majalah Telangke, Nomor: 5 Tahun 1/1996, h. 45.

${ }^{19}$ Pinan, Sumang, h 43. Lihat juga, A.R. Hakim Aman Pinan, 1001 Pepatah Petitih Gayo (Takengon: Penerbit Buku Adat dan Budaya Gayo, 1992), h. 140.

${ }^{20} \mathrm{Al}$-insân al-kâmil berasal dari bahasa Arab, yaitu dari dua kata: insân dan kâmil. Secara harfiah, insân berarti manusia, dan kâmil berarti yang sempurna. Baca, Muhammad Yunus, Kamus Arab-Indonesia (Jakarta: Hidakarya, 1990), h. 51 dan 387.

${ }^{21}$ Ibn Qayyim al-Jauziyah, Taman Orang-Orang Jatuh Cinta \& Memendam Rindu, terj. Kathur Suhardi (Jakarta: Dâr al-Falah, 2012), h. 85.

${ }^{22}$ Wawancara dengan bapak Drs. Azharia, tokoh masyarakat Gayo Kala Lengkio Kebayakan, pada tanggal 3 Juli 2017 di Takengon Kabupaten Aceh Tengah.

${ }^{23}$ Kata wâhid artinya satu atau esa, makna harfiah tawhîd ialah menyatukan atau mengesakan. Nurcholish Madjid, Islam Doktrin \& Peradaban (Jakarta: Paramadina, 1992), h. 72.

${ }^{24}$ Pengertian tazkiyat al-anfus adalah pensucian diri yang bisa berbentuk menahan diri dari hawa nafsu, syahwat, dan amarah. Membersihkan diri dari sifat-sifat tercela, atau melakukan latihanlatihan jiwa (riyadhat al-nafs) dalam berbagai disiplin, termasuk berpuasa, 'uzlah, dan latihan
} 


\section{Sumang Pelangkahen (Sumbang Perjalanan)}

Sumang Pelangkahen adalah apabila pria dan wanita pergi berjalan-jalan tanpa mahram. ${ }^{25}$ Bahkan apabila ada pria memisahkan diri dari orang seperjalanan atau berjalan sendiri secara tersembunyi-sembunyi dan menuju ke suatu tempat yang sepi dengan niat dan maksud berhubungan dengan wanita yang bukan mahramnya, juga dipandang sebagai Sumang Pelangkahen. Apabila kakak perempuan dan adik laki-lakinya berjalan berdua-duaan di tengah jalan, atau abang dan adik wanitanya bergandengan tangan di jalanan adalah Sumang Pelangkahen, sebab dugaan orang lain, bahwa kakak dan adik laki-lakinya adalah suami dan istri, padahal mereka saudara kandung, karena itu dilarang menurut adat Gayo.

\section{Sumang Penengenen (Sumbang Pendengaran)}

Sumang Penengenen berarti tabu atau pantang mendengar pembicaraan orang lain. Seorang laki-laki dan wanita sedang berbisik-bisik di tempat sepi tergolong Sumang Penengenen yang sangat dilarang. Sumang Penengenen ini bukan hanya ditujukan kepada orang yang sedang berbisik-bisik, tetapi juga ditujukan kepada orang-orang yang mendengar pembicaraan orang yang sedang berbisik-bisik tersebut. Apalagi orang laki-laki dan perempuan itu berbisikbisik kotor dan menjurus kepada yang tidak patut dan tidak pantas untuk dibicarakan, seperti orang tua tidak pantas bicara tentang hubungan suami dan istri di depan anak-anaknya, hal ini juga dianggap sebagai Sumang Penengenen.

\section{Sumang Kenunulen (Sumbang Kedudukan)}

Sumang Kenunulen (kedudukan) yaitu duduk di satu tempat yang dapat diduga tidak baik dan menimbulkan kecurigaan. ${ }^{26}$ Menurut Mahmud Ibrahim, bahwa Sumang Kenunulen adalah menggunakan tempat tidak pada fungsinya dan tidak menghormati orang lain yang sedang duduk di tempat itu dapat dipandang sebagai Sumang Kenunulen. ${ }^{27}$ Sedangkan A.R. Hakim Aman Pinan mengatakan bahwa "dianggap sumbang cara duduk (Sumang Kenunulen) bila umpamanya dalam satu ruangan, antara ayah atau mertua dan anak atau menantu duduk saling bertemu lutut, hingga tanpa ada rasa sungkan lagi terhadap orang tua. Dalam tradisi Gayo ini dianggap sebagai Sumang Kenunulen. ${ }^{28}$

jiwa yang lainnya". Mulyadhi Kartanegara, Menyelami Lubuk Tasawuf (Jakarta: Erlangga, 2006), h. 5 .

${ }^{25}$ Abdurrahim Ali, "Peranan Islam Melalui Adat Gayo dalam Pembangunan Mayarakat Gayo," Makalah Seminar Ilmu Pengetahuan dan Kebudayaan pada tanggal 20-24 Januari 2006 di Takengon, h. 29.

${ }^{26}$ Ibid., h. 28.

${ }^{27}$ Mahmud Ibrahim, "Peranan Islam Melalui Adat Gayo dalam Pembangunan Masyarakat Gayo," Makalah Seminar Nasional Ilmu Pengetahuan dan Kebudayaan (Takengon: MUI Aceh dan MUI Kabupaten Aceh Tengah, 20-24 Januari 1986), h. 20.

${ }^{28}$ Baca, Pinan, "Budaya Sumang yang Menjadi Sumbang," h. 43. 


\section{Sumang Perupuhen (Sumbang Berpakaian)}

Sumang Perupuhen mengandung pengertian bahwa apabila seseorang yang memakai busana secara ketat, sempit, tipis, dan you can see (kamu dapat dilihat), sehingga dipandang tidak sopan dan kurang pantas dilihat dan orang yang melihatnya menimbulkan risih dan hawa nafsu, atau wanita yang berpakaian, tetapi pada hakikatnya adalah telanjang, lenggak lenggok dan transparan. Inilah yang disebut Sumang Perupuhen. Menurut Bapak Julia bahwa apabila pria dan wanita berpakaian tidak sopan, tipis, ketat, dan transparan sangat dilarang. Karena hal itu dianggap sebagai Sumang Perupuhen yaitu berpakaian sembarangan, dalam bahasa Gayonya disebut berupuh kune kenak perlu ditinggalkan. ${ }^{29}$

\section{Sumang Penosahen (Sumbang Pemberian)}

Sumang Penosehen adalah seorang laki-laki memberikan sesuatu pada wanita yang bukan mahramnya untuk maksud dan tujuan tertentu tanpa ada perhitungan, sedangkan kepada orang lain ia bersikap kikir. Dalam istilah Gayo disebut Kujema dele tikik, ku sara jeme dele. Artinya pemberian kepada orang banyak sedikit, sedangkan kepada satu orang banyak. ${ }^{30}$ Kepada satu orang dimaksudkan adalah ada hubungan spesial si pemberi dan si penerima dengan maksud tertentu, atau ada seorang pria memberikan sesuatu pada wanita dengan niat berbuat seksual, maka pemberian dengan maksud seperti itu, dipandang sebagai Sumang Penosahen. Tetapi jika pemberian itu tanpa niat jahat, melainkan dengan keikhlasan, hal itu bukan Sumang Penosahen, melainkan sedekah jariyah, yaitu pemberian dengan ikhlas sebagai bentuk amal ibadah untuk memperoleh rida dari Allah SWT. ${ }^{31}$

\section{Sumang Perceraken (Sumbang Perkataan)}

Sumang Perceraken adalah perkataan yang diungkapkan oleh seseorang kepada orang lain tidak sesuai dengan ajaran Islam dan adat sopan santun. Perkataan seperti itu disebut cerak enta sesanah (Perkataan yang bukan-bukan). Dalam istilah ajaran Islam disebut qaul al-zur (perkataan keji). ${ }^{32}$ Sumang Perceraken merupakan pembicaraan antara pria dan wanita mengenai hal-hal yang tidak pantas dan tidak wajar dibicarakan. Sumang Perceraken ini bukan hanya ditilik dari segi kata-kata, tetapi juga dari segi penyesuaian waktu, tempat,

${ }^{29}$ Penulis melakukan wawancara dengan Kepala MTsN Pegasing Bapak Julia, pada hari Kamis tanggal, 6 Juli 2017 di Aceh Tengah Takengon.

${ }^{30}$ Baca, Ibrahim, "Peranan," h. 20.

${ }^{31}$ Sedekah jariyah adalah sedekah atau amal yang kemanfaatannya berlangsung secara terusmenerus tanpa terputus, sehingga pahalanya pun mengalir terus. Makna sedekah itu sendiri adalah pemberian dari seorang Muslim secara sukarela tanpa dibatasi waktu dan jumlah tertentu, kepada orang-orang yang membutuhkan, yang dilakukan sebagai kebajikan untuk mengharap rida dari Allah SWT. Karena itu, pemberian dalam bentuk sedekah jariyah adalah merupakan amal ibadah, bukan termasuk dari Sumang Penosahen. Wawancara dengan Hakim Majedi, tokoh adat Gayo Aceh Tengah pada tanggal,07 Juli 2017 di Takengon.

32Ibrahim, "Peranan," h. 20. 
keadaan, dan cara mengungkapkan perkataan tersebut. Mungkin isi atau substansi, tujuan, dan maksud kata-kata yang diungkapkan itu baik, namun karena waktu dan tempat serta keadaan mengungkapkan tidak tepat, maka ucapan seperti itu dipandang sebagai Sumang Perceraken.

\section{Sumang Pergaulen (Sumbang Pergaulan)}

Sumang Pergaulen adalah larangan bergaul, hidup berteman, atau hidup bersahabat dengan bebas. Jadi, Sumang Pergauelen merupakan tabu, pantang, atau larangan bergaul secara bebas antara pria dan wanita yang bukan mahramnya. Dari segi bahasa pergaulan artinya proses bergaul, sedangkan bebas artinya terlepas dari ikatan. Karena itu, pergaulan bebas dianggap sebagai Sumang Pergaulen.

\section{Sumang Perbueten (Sumbang Perbuatan)}

Sumang Perbueten adalah apabila ada seseorang melakukan perbuatan, seperti menyentuh, apalagi memegang wanita yang bukan mahramnya dengan sengaja. Seseorang baru dapat dianggap telah melakukan Sumang Perbueten apabila terdapat beberapa syarat pembuktian adalah sebagai berikut. Pertama, syarat Jirim-jisim yaitu jelas pelakunya, bukan dugaan. Kedua, syarat jirim johar yaitu perbuatan sumang diketahui oleh orang lain. Ketiga, syarat jirim salah satu pelaku perbuatan sumang memisahkan diri secara diam-diam dari pergaulan yang biasa. ${ }^{33}$

Menjaga Sumang Perbueten perlu melakukan amar makruf nahi mungkar dan harus dilaksanakan prinsip tanggung jawab. Pertama, ukum ni anak iamaye (bapak wajib dan bertanggung jawab sepenuhnya mengatur kehidupan anaknya. Sebaliknya, anak wajib patuh dan hormat kepada bapaknya atau orang tuanya). Kedua, ukum ni rayat i rejeye (pemimpin pemerintahan bertanggung jawab mengenai tingkah laku rakyatnya). Ketiga, ukum ni hartai empuye (pemilik harta yang sah bertanggung jawab memelihara dan memanfaatkan hartanya). ${ }^{34}$

\section{Makna Restorasi Karakter Masyarakat Gayo}

Restorasi karakter anak bangsa atau negeri menjadi suatu keniscayaan jika masingmasing ingin anak bangsa/negeri memiliki kelebihan dari anak-anak lain, bukan pembeo bagi mereka. Restorasi dapat diartikan sebagai to bring back or to put back into the former

${ }^{33}$ Wawancara Mahmud Ibrahim dengan Ali Hasan Aman Kamalentan 1972 dalam Ibrahim, "Peranan," h. 21.

${ }^{34}$ Wawancara Syukri dengan Usman Ralibi, tokoh adat Gayo atau Petue (petua) di desa Kala Lengkio Kebayakan, 15 Pebruari 2003. 
or original state, atau to bring from a state of change condition. ${ }^{35}$ Artinya, bahwa restorasi adalah upaya mengembalikan pada landasan aslinya atau mengembalikan dari perubahan yang terjadi.

Karakter sering diberi padanan kata watak, tabiat, perangai dan akhlak. Karakter adalah suatu kualitas yang mantap dan khusus (furqân) yang terbentuk dalam kehidupan individu yang menentukan sikap dalam mengadakan reaksi terhadap rangsangan, dipengaruhi oleh faktor endogeen (dalam diri) dan exogeen (luar diri manusia). ${ }^{36}$ Sementara itu, Hugo mengartikan karakter sebagai stabilitas, kekuatan, atau kebaikan hati personal. Terkait pula dengan nilai rangsang sosial seorang individu dan keseluruhan hakikat wataknya. ${ }^{37}$ Jadi, karakter adalah suatu nilai yang sangat urgen yang diwujudkan dalam tingkah laku.

Karakter merupakan bagian integral yang harus dibina dan dibangun, agar gernerasi muda dan masyarakat memiliki sikap dan pola pikir yang berlandaskan moral ${ }^{38}$ Pembinaan karakter bagi kehidupan generasi muda sangat urgen, sebab pembinaan karakter merupakan fitrah Allah SWT. Dengan fitrah yang di dalamnya terkandung makna yang paling mendasar tentang kebenaran (haq), kehidupan yang dianugerahkan Allah SWT., kepada makhlukNya, khususnya kepada generasi muda terarah kepada kondisi yang optimal, yaitu kehidupan manusia dengan fitrahnya itu, yang terhimpun dalam harkat, martabat dan hakikat manusia. ${ }^{39}$

Kalau karakter anak bangsa ini telah luntur tergerus arus global menjadi sikap tidak berkarakter mulia, kurang terpuji, tidak sopan, tidak memiliki rasa malu, dan mementingkan diri sendiri (egois), serta seakan-akan tidak tahu dimana posisinya (dislocation), mencaci maki, tidak bersahabat, penuh kekerasan dan kebencian, maka hal itu perlu direstorasi agar kembali bersikap peduli, tahu posisi dan apa yang diperbuatnya, mau berbuat terpuji dan terhormat. Namun yang menjadi persoalan yang dihadapi negeri ini adalah karakter anak bangsa yang semakin merosot dan memprihatinkan. Menurut Syahrin Harapap, bahwa secara tidak terelakan saat ini sedang menangisi kemerosotan perilaku sebagian besar anak negeri telah menyimpang dari karakter mulia. Kemerosotan itu dapat diilustrasikan sebagai berikut:

${ }^{35}$ Lebih rinci lagi dapat merujuk kepada, Muhammad Arkoun, Islam: to Reform or Subvert (London: Sagi Essantials, 2006), h. 154-200.

${ }^{36}$ Lihat, Syahrin Harahap, "Guru di Tengah Restorasi Karakter Bangsa," Makalah disampaikan pada Seminar "Tenaga Kependidikan dan Pembangunan Karakter Bangsa Sekolah Tinggi Agama Islam (STAI) al-Hikmah Medan, 4 April 2012, h. 2.

${ }^{37}$ Hugo, "Dictionary of Social Science," h. 52.

${ }^{38}$ Istilah moral dari segi bahasa berasal dari bahasa Latin, mores, yaitu jamak dari kata mos yang berarti adat kebiasaan. Lihat, Asmaran As, Pengantar Studi Akhlak (Jakarta: Rajawail Press, 1992), h. 8. Dalam Kamus Umum Bahasa Indonesia, dijelaskan bahwa moral adalah penentuan baik dan buruk terhadap perbuatan dan kelakukan. Lihat, W.J.S. Poerwadarminta, Kamus Umum Bahasa Indonesia (Jakarta: Balai Pustaka, 1991), h. 654.

${ }^{39}$ Hakikat manusia, meliputi lima unsur, yaitu bahwa manusia diciptakan sebagai makhluk yang beriman dan bertakwa, paling sempurna, paling tinggi derajatnya, khalifah di muka bumi, dan penyandang HAM (Hak Asasi Manusia). Pembentukan karakter sepenuhnya mengacu kepada kelima unsur hakikat manusia ini. 
Sebagian masyarakat kita sudah tidak mampu lagi membedakan perilaku baik dan buruk, terhormat dan terhina, perbuatan mulia dan nista. Akibatnya bukan tanggung-tanggung, Penguasa yang seharusnya memikirkan rakyatnya, menjadi memikirkan diri sendiri dan golongan dan kabilahnya saja, ulama dan cendekia yang seharusnya menjadi penasihat penguasa menjadi pengecut dan hina di hadapannya, anak-anak yang seharusnya mengidolakan orang tua dan gurunya, akhirnya mengidolakan orang asing atau artis yang tak jelas ujung pangkalnya, atau bahkan politik busuk, yang memperkaya diri atas nama yang diwakilinya, masyarakat kita menjadi kasar dan tidak bersemi lagi nilai-nilai keindonesiaan yang tersimpul dalam Pancasila. Masih banyak lagi akibat dari kerusakan karakter bangsa yang tidak bisa dibahas dalam tulisan ini" ${ }^{40}$ Melihat kondisi yang sangat memprihatinkan ini, kita perlu menyapa diri, bagaimana kita harus memperbaiki keadaan, sebab apabila dibiarkan kemerosotan karakter bangsa akan menyeret anak negeri ini kepada situasi yang terhina dan terjajah di negerinya sendiri? ${ }^{41}$ Tentu jawaban yang paling tepat adalah restorasi kepada kekuatan akidah yang benar dengan membangun masyarakat akidah yang lurus dan yang benar pula. Karena itu, masyarakat Gayo harus berpijik pada akidahyang benar, akhlak mulia dan nilai-nilai seperti; oleh pikir, olah hati, olah rasa, olah raga dan olah karsa. ${ }^{42}$

\section{Implementasi Budaya Sumang Gayo}

Implementasi budaya sumang terhadap restorasi karakter masyarakat Gayo di Aceh diselenggarakan sebagai usaha sadar dan terencana untuk meningkatkan kualitas sumber daya manusia, sehingga dapat menjangkau ranah-ranah hasil pembelajaran, baik peningkatan dalam ranah kognitif, afektif dan psikomotorik dalam bentuk perubahan sikap, perilaku, karakter dan memajukan budi pekerti serta pikiran. Budaya sumang di samping sebagai tradisi juga merupakan suatu sistem, bentuk, dan model pendidikan tertua di negeri antara Tanah Gayo, meskipun pada awalnya model pendidikan Sumang Gayo ini tidak tertulis dan tidak diajarkan secara formal di lembaga pendidikan serta tidak memiliki kurikulum resmi, namun pendidikan Sumang ini tetap berlaku untuk mendidik dan membina remaja, pemuda, dan masyarakat dari perbuatan amoral dan tingkah laku tercela.

Menurut A.R. Hakim Aman Pinan, apabila sempat bertindak melakukan yang sifatnya

${ }^{40}$ Harahap, "Guru," h. 1.

${ }^{41}$ Dalam perspktif pemikiran Islam dikenal adanya hukum pinjam meminjam budaya, yang salah satunya adalah unsur-unsur yang dipinjam hanya mendorong vitalitas yang berkembang dan kebudayaan peminjam. Jika unsur-unsur itu berkembang sedemikian subur sehingga mengancam atau menggantikan budaya peminjam, maka sifatnya akan berubah menjadi destruktif bukan konstruktif. C.A. Qadir dalam Filsafat dan Ilmu Pengetahuan dalam Islam (Jakarta: Obor Indonesia, 1989), h. 27.

${ }^{42}$ Prayitno \& Afriva Khaidir, Model Pendidikan Karakter-Cerdas (Padang: UIN, 2010), h. iii. 
negatif, jelas masyarakatnya pasti menolak, atau tidak dapat menerimanya. Sebenarnya sumang ini dapat dilihat dari segi tingkah laku manusianya sehari-hari. ${ }^{43}$

Menilai sumang perlu dilihat dalam penjelmaan sikap lewat perbuatan gerak-gerik yang dipandang tidak serasi dengan kebiasaan-kebiasaan. Hal itu tergolong kepada perbuatan sumang. Orang yang bertindak sumang, dinilai tidak sopan, salah, dan tidak baik. Bahkan suatu perbuatan yangsangat memalukan, karena itu, sistem pendidikan sumang ini memiliki kekuatan hukum dan mewarnai seluruh aspek hidup dan kehidupan seseorang dalam sehari-harinya. Di sinilah model utama dari pendidikan Sumang ini. ${ }^{44}$ Lebih penting lagi berdasarkan sendi-sendi psikologis seseorang yaitu keimanan, ketaqwaan, ${ }^{45}$ dan selalu mendorong untuk berperan nyata dalam kehidupan yang melahirkan sikap hidup yang baik serta berlomba-lomba kepada kebaikan sesuai dengan Firman Allah SWT, "maka berlomba-lombalah berbuat kebajikan. Hanya kepada Allah-lah kembali kamu semuanya, lalu diberitahukan-Nya kepadamu apa yang telah kamu perselisihkan itu" (Q.S. al-Mâłidah/ 5: 48$).{ }^{46}$

Budaya sumang mengandung nilai. ${ }^{47}$ Nilai yang dimaksudkan merupakan esensi yang melekat pada suatu yang sangat berarti bagi kehidupan masyarakat Gayo. Esensi itu merupakan rujukan dan keyakinan dalam menentukan pilihan. Esensi itu sendiri belum berarti sebelum dibutuhkan oleh manusia, tetapi bukan berarti adanya esensi karena adanya manusia yang membutuhkannya. Tetapi yang jelas budaya sumang tetap sangat dibutuhkan oleh manusia, terutama masyarakat karena mengandung nilai keberhargaan, kebaikan, dan manfaat masyarakat. ${ }^{48}$

Sistem budaya sumang tetap hangat dibicarakan (up to date) sepanjang sejarah masyarakat Gayo terus membangun untuk mencapai tarap kehidupan yang lebih baik dan sempurna. Masyarakat terus berlomba untuk mengembangkan kreasi mereka di bidang pendidikan dan kebudayaan, yang selaras dengan fitrahnya yang hendak maju dan berkembang. Allah dan rasul-Nya telah menyuruh umat manusiabekerja keras dan beramal untuk membuat

${ }^{43}$ Lebih rinci dalam merujuk kepada A.R. Hakim Aman Pinan, Hakikat Nilai-Nilai Budaya Gayo Aceh Tengah (Takengon: Pemerintah daerah Kabupaten Aceh Tengah, 1998), h. 89.

${ }^{44}$ Wawancara dengan Guru Muatan Lokal, Pendidikan Sumang Ibu Raidani, Abidah, Bapak Mukhtar pada 10Juli 2017 di Ruang Guru MTsN Pegasing Kabupaten Aceh Tengah di Takengon.

${ }^{45}$ Istilah bertakwa berasal dari bahasa Arab yaitu taqwa yang berarti takut kepada Allah yang dilaksanakan dengan "menjauhi segala larangan-Nya, menjalankan semua perintah-Nya." Karena itu taqwa adalah sebuah dasar kemanusiaan. Takwa menyatakan seluruh kemanusiaan. Lebih rinci baca, M. Dawam Raharjo, Ensiklopedi Al-Qur'an: Tafsir Sosial Berdasarkan Konsep Kunci (Jakarta: Paramadina, 2002), h. 155 dan 167.

${ }^{46}$ Departemen Agama RI, Alquran dan Terjemahnya (Jakarta: Yayasan Penyelenggara Penterjemah al-Qur'an, 1995), h. 168.

${ }^{47}$ Pengertian nilai Inggris: value. dari bahasa Latin valere (berguna, mampu, akan berdaya, berlaku, kuat). Lihat, Bagus, Kamus Filsafat, h. 713

${ }^{48}$ Wawancara dengan Guru Mulok Pendidikan Sumang Ibu Raidani, pada hari Rabu, 10 Juli 2017 di Ruang Guru MTsN Pegasing Kabupaten Aceh Tengah di Takengon. 
kebudayaan baru, membangun di segala bidang kehidupan manusia seperti ekonomi, sosial, budaya, politik, dan teknik, termasuk berbarengan dengan pembangunan di bidang pendidikan, mental, moral dan spiritual. ${ }^{49}$ Nilai-nilai budaya sumang memiliki nilai ganda antara dunia dan akhirat. Hal ini selaras dengan firman Allah dalam al-Qur'an "Dan carilah pada apa yang telah dianugerahkan Allah kepadamu (kebahagiaan) negeri akhirat, dan janganlah kamu melupakan bahagianmu dari (kenikmatan) duniawi" (Q.S. al-Qashash/28: 77). ${ }^{50}$

Budaya sumang Gayo sejalan dengan spiritual, moral, etika, dan material yang seimbang. Pembangunan spiritual amat penting dan merupakan faktor mutlak dalam menyertai pembangunan material. ${ }^{51}$ Pembangunan spiritual meliputi pembinaan akidah, syariah dan akhlak sebagai nilai-nilai penting dalam sistem budaya sumang.Untuk mewujudkan pembangunan karakter masyarakat diperlukan penanaman nilai-nilai budaya sumang yang relevan dengan ajaran Islam dalam berbagai sendi kehidupan masyarakat Gayo di Aceh. ${ }^{52}$

Nilai-nilai penting dalam budaya sumang dikenal prinsip Edet kuet muperala agama, rengang edet benasa nama, edet munukum bersifet ujud, ukum munukum bersifet kalam. (Adat dituntun oleh hukum. Adat menghukum bersifat wujud. Hukum agama itu adalah pasti). Edet mungenal, ukum mubeza (Adat mencari mana yang benar dan mana yang salah. Hukum membedakan mana yang benar dan mana yang salah). ${ }^{53}$ Adat berfungsi untuk melaksanakan hukum berdasarkan kenyataan. Sedangkan hukum berdasarkan Firman Allah dan Rasul-Nya.

Menurut Tgk. H. Abdullah Husni, dalam budaya sumang, nilai hukum dan adat-istiadat menghukum bersifat wujud. Artinya kata adat itu selaras dengan ketentuan hukum. Hukum

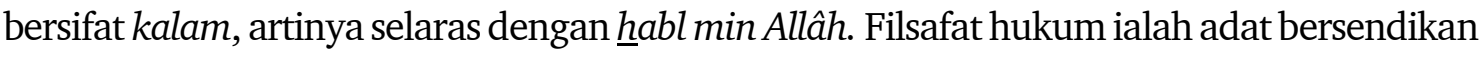
syara', syara'bersendikan pada adat. Adat-istiadat itu tidaklah kuat dan kokoh kalau tidak

${ }^{49}$ Istilah spiritual adalah sebuah istilah yang berkaitan dengan filosofis dan religius. Secara filosofis, kadang istilah ini digunakan sebagai sinonim Idealisme. Dalam agama, adakalanya istilah ini mengacu kepeda penjelmaan Roh. Bagus, Kamus, h. 1035. Istilah spiritual bahwa siapa saja yang memandang Tuhan atau Ruh Suci sebagai norma yang penting dan menentukan atau prinsip hidupnya bisa disebut spiritual. Baca, Seyyed Hossein Nasr, Ensiklopedi Tematis Spiritualisme Islam, terj. Rahmani Astuti (Bandung: Mizan Media Utama, 2002), h. 13.

${ }^{50}$ Departemen Agama RI, al-Qur'an, h. 623.

${ }^{51}$ Pada hakikatnya pembangunan Indonesia-Aceh yang lagi berupaya penerapan syariat Islam. Karenanya yang ideal adalah mencakup fisik-material dan mental-spiritual, sebagaimana unsur diri manusia itu sendiri. Antara keduanya hendaknya seimbang, sehingga tidak berat sebelah. Ketika hanya mementingkan dan mengutamakan pembangunan fisik, maka pembangunan mentalruhaniah akan terabaikan dan kondisi semacam itu akan membentuk manusia-manusia yang materialis, "pincang", dan "sekuler". Misri A. Muchsin, Potret Aceh dalam Bingkai Sejarah (Banda Aceh: ArRaniry Press, 2007), h. 184.

${ }^{52}$ Mahmud Ibrahim, "Peranan Islam Melalui Adat Gayo," h. 8.

53Pinan, 1001 Pepatah Petitih Gayo, h. 36. 
bersumber kepada syara'. Hukum syara'tidak akan terwujud, terealisasi, dan menjadi kenyataan dalam kehidupan masyarakat kalau tidak dijadikan hukum adat sebagai pendukungnya. ${ }^{54}$

Dengan demikian, masyarakat Gayo harus berpegang kepada hukum Islam dan adat. Dalam ungkapan adat dikenal ukum urum edet, lagu jet urum sifet. Artinya, hukum Islam dan adat seperti zat dengan sifat, sukar dipisahkan. ${ }^{55}$ Karena itu, nilai-nilai budaya sumang tidak terlepas dari ketentuan hukum Islam dan adat istiadat, seperti Genap mupakat syura (musyawarah), amanat (amanah), tertib, alang tulung beret bantu (saling-tolong menolong), gemasih (kasih sayang), setie (setia), bersikekemelen (berkompetisi), dan mutentu (berdayaguna). Nilai-nilai budaya sumang dalam pembangunan material dan spiritual lihat skema berikut:

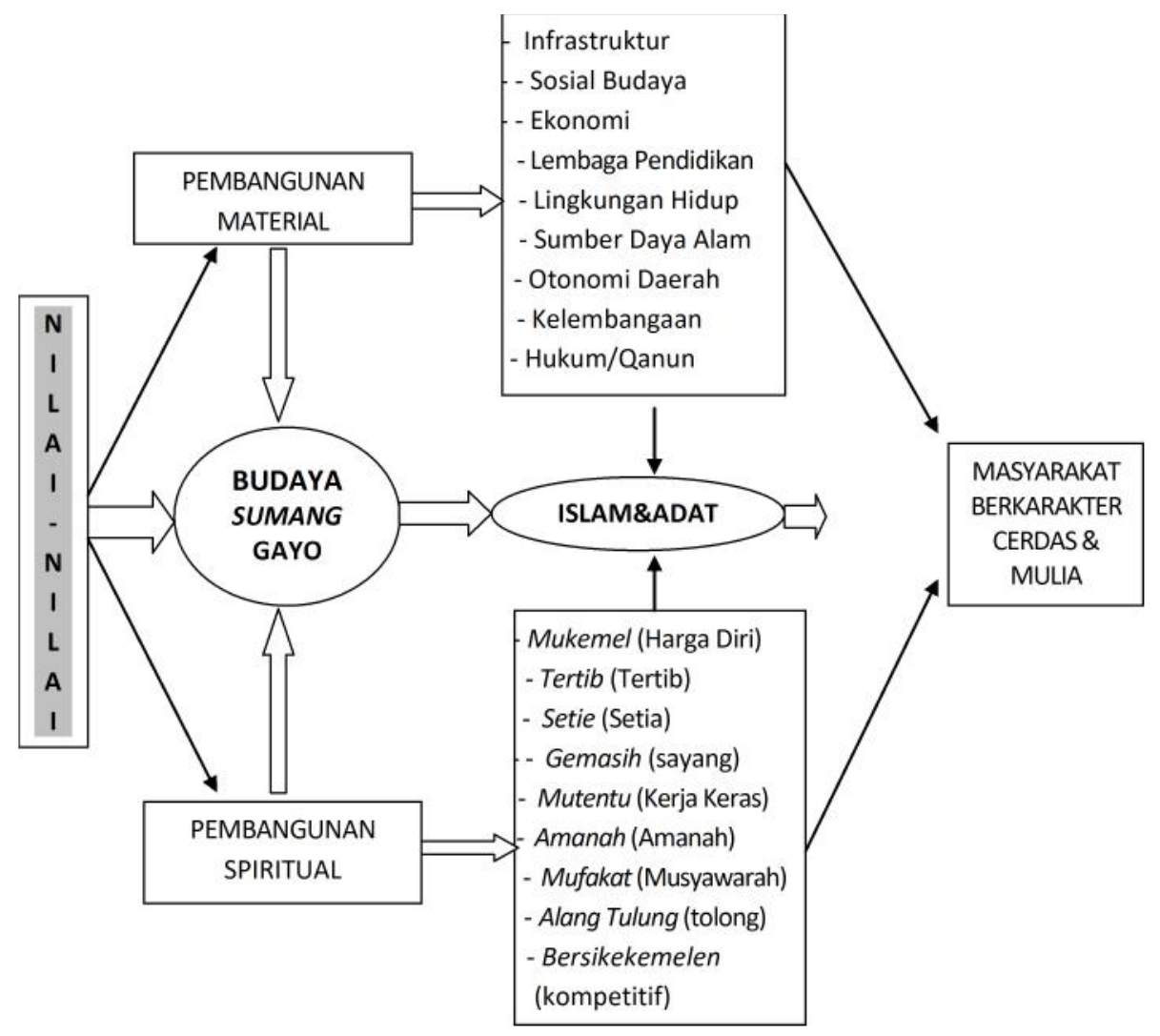

Skema di atas, menunjukkan bahwa nilai-nilai budaya sumang yang dapat diimplementasikan dalam upaya merestorasi karakter masyarakat Gayo. Nilai adat dan budaya itu terbagi tiga kategori, yaitu nilai utama, nilai penunjang dan nilai pendorong. Sistem nilai itu tampak seperti dalam skema di bawah ini: ${ }^{56}$

${ }^{54}$ Syukri, Sarakopat: Sistem Pemerintahan Tanah Gayo dan Relevansinya terhadap Pelaksanaan Otonomi Daerah (Jakarta: Pustaka Utama, 2006), h. 160.

${ }^{55}$ Abdurrahman Ali, "Peranan Islam Melaui Adat Gayo," h. 1.

${ }^{56}$ M. Junus Melalatoa, "Budaya Malu: Sistem Budaya Gayo," dalam Sistem Budaya Indonesia (Jakarta: Fakultas Ilmu Sosial dan Ilmu Politik Universitas Indonesia dan Pelajar-Indonesia, 1997), h. 203. 


\section{SKEMA SISTEM NILAI BUDAYA GAYO}

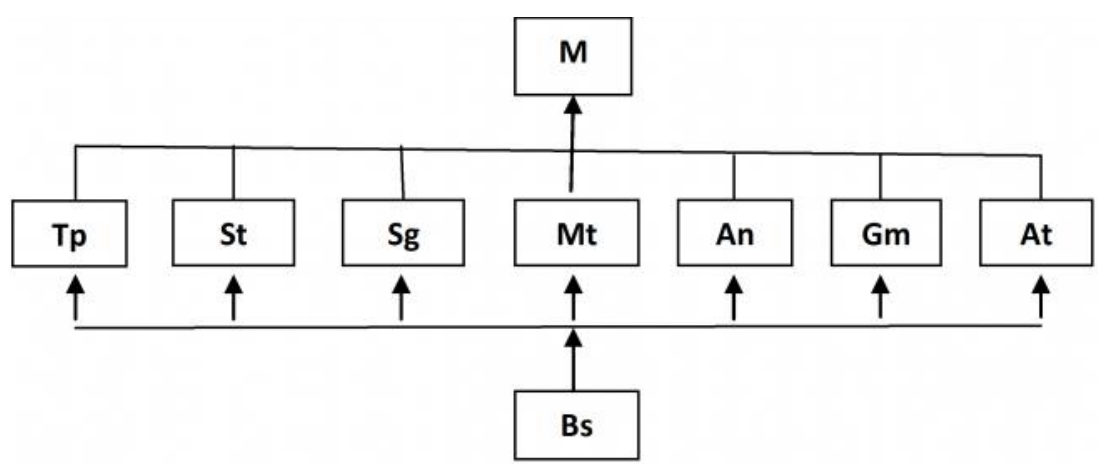

Skema di atas, dapat dijelaskan, bahwa nilai utama adalah harga diri (mukemel-M), yang idealnya menjadi milik diri setiap individu. Seorang baru bisa meraih nilai itu apabila ditunjang oleh adanya pengamalan sejumlah nilai lainnya (nilai penunjang). Nilai penunjang yang dimaksud adalah tertib (tertib-tp), setia, (setie-st), kasih sayang (semayang gemasih$s g$ ), rajin (mutentu-mt), menjalankan amanah (amanah-an), musyawarah-mufakat (genap mupakat-gm), tolong menolong (alang tulung-at). Pengamalan nilai penunjang ini digerakkan oleh sebuah nilai lain (nilai penggerak), yaitu nilai kompetitif (bersikekemelen-bs) ${ }^{57}$ Nilai adat dijelaskan sebagai berikut:

\section{Nilai Harga Diri (Mukemel)}

Pada masa lalu masyarakat Gayo telah merumuskan prinsip-prinsip adat yang terkenal dengan sebutan kemalun ni edat (pantangan adat). Nilai atau prinsip adat itu menyangkut harga diri ( $k e m e l=m a l u$ ) yang harus dijaga, diamalkan, ditegakkan, dan dipertahankan oleh kelompok kerabat tertentu, kelompok satu rumah (sara umah), klien atau belah, dan kelompok yang lebih besar lagi. Nilai mukemel itu diimplementasikan dalam merestorasi karakter masayarakat Gayo. Prinsip budaya sumang ini meliputi empat pantangan adat. ${ }^{58}$ Pertama, malu tertawan (wanita ditawan orang) harga diri yang terusik karena kaum wanita dari kelompoknya diganggu atau difitnah kelompok lain, atau anak perempuan dilarikan dan ditawan oleh kelompok dari klien lain. Kedua, bela mutan (pembelaan digagalkan orang) sehingga seseorang tidak dapat lagi membela atau memulihkan haknya. Ketiga, negeri terpancang (negeri diganggu orang) wajib dipertahankan, yakni harga diri yang menyangkut hak-hak atas wilayah wajib dijaga. Keempat, nahma teraku (penghinaan merusak nama baik) harus dipulihkan dan dibela, sehingga nama baik kedaulatan, bangsa, masyarakat, keluarga dan perorangan tetap terpelihara, harga diri yang menyangkut kedudukan tetap sah. ${ }^{59}$

${ }^{57}$ Ibid., h. 204.

${ }^{58}$ Mahmud Ibrahim, "Peranan Islam Melalui Adat Gayo," h.4.

${ }^{59}$ Abdurrahman Ali, "Peranan Islam Melalui Adat Gayo," h. 29. 


\section{Nilai Tertib (Tertib)}

Tertib sebagai sistem nilai yang diterapkan dalam merestorasri karakter masyarakat Gayo berarti teratur, menurut aturan, atau rapi. Antara tertib dan disiplin adalah erat sekali hubungannya. Bila tertib tidak dilakukan, sama halnya dengan centang perenang, semua kegiatan tidak terarah yang pada akhirya mengalami kegagalan atau tidak berhasil. Karena itu, dalam tertib, terkandung nilai, gagasan, konsepsi, norma, hukum yang bersamaan. ${ }^{60}$ Semua nilai yang terkandung dalam tertib di atas dapat dijadikan sebagai acuan dalam merestorasi karakter masyarakat Gayo. Dalam peribahasa Gayo nilai tertib ini diungkapkan dengan kalimat tertib bermajelis, umet bermelie (teratur dalam kebersamaan akan memuliakan umat). ${ }^{61}$

\section{Nilai Setia (Setie)}

Setie (setia) adalah faktor yang paling penting dalam pembinaan karakter masyarakat, tanpa setie,masyarakat tidak akan mencapai hasil yang maksimal. Dalam pribahasa Gayo disebutkan bahwa setie murip gemasih papa. Artinya, kesetiaan hidup karena kasih sayang, walaupun hidup itu merana. Kesetiaan yang dimotivasi rasa kasih sayang, menyebabkan orang rela berkurban, baik pikiran, tenaga, harta mapun jiwa, bahkan berakhir dengan kepapan atau kemiskinan. Perasaan sosial bagi orang yang menghayati dan melaksanakan nilai ini amat tinggi, karena mereka menyadari bahwa manusia adalah makhluk sosial, tidak mungkin ia bisa hidup sendirian untuk meraih kesejahteraan dan kebahagian. Mereka harus setia, seiya dan sekata dalam mencapai tujuan hidup.

\section{Nilai Kasih Sayang (Semayang/Gemasih)}

Dalam pribahasa masyarakat Gayo bahwa kasih enti lanih, sayang entilelang. Artinya bila kasih janganlah terlambat, andaikan sayang jangan pula setengah hati. ${ }^{62}$ Dalam Pendidikan Sumang ini kata semayang/gemasi $h^{63}$ merupakan ciri khas yang sangat urgen dipertahankan,

${ }^{60}$ A.R. Hakim Aman Pinan, Hakikat Nilai-Nilai Budaya Gayo Aceh Tengah (Banda Aceh: Pemerintah Daerah Kabupaten Aceh Tengah, 1998), h. 70.

${ }^{61}$ Dalam pribahasa Gayo di atas, perlunya tertib dalam Dewan atau rapat yang mengemban tugas untuk membicarakan sesuatu hal. Berkumpul seperti ini dipandang pekerjaan yang paling mulia. Dalam hidup dan kehidupan ini, tertib itu adalah modal pokok. Tertib itu berlaku di segala masalah, serta berlaku kepada siapapun. Dilihat dari pandangan adat, bila tidak tertib bisa saja sewaktu menjurus pada pantangan adat, bila sempat terjadi tentu saja mengandung keresahan masyarakat dan tidak mustahil akan menerima sanksi adat yang berlaku. Pinan, Hakikat, h. 70 .

${ }^{62}$ Pribahasa Gayo di atas lebih jelasnya baca, Pinan, 1001 Pepatah Petitih Gayo, h. 68.

${ }^{63}$ Makna semayang/gemasih (kasih sayang) di sini tentu relatif luas.Penempatan makna (meaning) bergantung kepada si pemakainya. Maksudnya, kasih sayang pada kedua orang tua (ibu dan bapak) bentuknya lain bila dibandingkan dengan kasih sayang kepada orang miskin yang membutuhkan pertolongan. Kasih sayang pada teman sangat berbeda dengan kasih sayang kepada orang yang bukan teman, kasih sayang pada seorang siswa dan siswi sangat beda dengan kasih sayang kepada kakak dan abangnya. Karena itu, kasih sayang itu sangat relatif dan subjektif bagi orang yang memilikinya. Pinan, Hakikat, h. 82. 
diimpelementasikan dan dilestarikan, dalam pembinaan karakter masyarakat Gayo yang mulia, sejahtera, dan bermartabat. Karena implementasi semayang/gemasaih pada orang lain tepat pada waktunya, adalah kasih sayang yang sejati dan abadi serta amat berguna bagi orang yang dikasihi. Namun pembuktian kasih sayang yang dilakukan pada waktunya adalah bentuk kasih sayang yang paling sempurna. Sebaliknya, kasih sayang yang tidak tepat waktunya, sering mengakibatkan bencana seperti terlalu memanjakan masyarakat, membantu orang lain dalam jumlah yang sangat besar, tetapi dilakukan dengan sombong, angkuh, dan congkak, hal itu tidak dibenarkan dalam sistem budaya sumang.

\section{Nilai Kerja Keras/Berdaya Guna (Mutentu)}

Mutentu amat penting dalam pembinaan karakter masyarakat Gayo, karena mutentu adalah pedoman yang baik dan berguna bagi siapa saja. Mutentu dapat juga diartikan terkendali, sifat mutentu, lebih diarahkan pada setiap pribadi seseorang. Dalam masyarakat Gayo, jika ada sesorang gadis yang mutentu sangat disenangi dan dihormati masyarakat, dan lazimnya akan segera dipinang orang menjadi calon menantu. Mutentu juga adalah orang yang rajin, bekerja keras dan sangat rapi dalam mengerjakan sesuatu. ${ }^{64}$ Sebaliknya orang yang tidak rajin dan tidak giat bekerja keras (gere mutentu) tidak disenangi masyarakat.

\section{Nilai Amanah (Amanah)}

Hakikat budaya sumang adalah melaksanakan amanah. ${ }^{65}$ Dalam peribahasa Gayo dinyatakan bahwa kukur amat tergukkee, akang amat terbekase, jema amat terlinge (Burung diketahui benar adalah burung balam, setelah didengar suaranya, rusa dapat dilihat sebagai bukti ialah bekas kakinya). ${ }^{66}$ Orang baru dipandang amanah apabila terbukti keabsahan segala perkataan sejalan dengan perbuatannya. Sebaliknya tidak selaras perkataan dan perbuatan, itu tandanya masyarakat yang tidak berkarakter cerdas dan mulia. Allah membenci orang beriman yang tidak sejalan perkataan dan perbuatannya sesuai Firman-Nya, "Wahai orang-orang yang beriman, kenapakah kamu mengatakan sesuatu yang tidak kamu kerjakan?. Amat besar kebencian di sisi Allah bahwa kamu mengatakan apa-apa yang tidak kamu kerjakan (Q.S. al-Shaff/61: 2-3). ${ }^{67}$

${ }^{64}$ Istilah mutentu disini dapat mengandung arti bahwa seseorang mampu menempatkan berbagai problema atau persoalan, dalam arti, siap menangani segala kemungkinan yang datang. Romantika hidup silih berganti, antara suka dan duka. Suka diterima dengan rasa syukur, apabila menemukan duka juga diterima dengan rasa sabar dan tawakkal. Ibid., h. 82.

${ }^{65}$ Dalam adat Gayo menurut Pinan bahwa maksud amanah ialah yang dipercayakan (dititipkan) kepada orang lain. Kemerdekaan Indonesia merupakan amanah pahlawan bangsa. Mengamanahkan, memercayakan, saudagar menitipkan hartanya kepada saudaranya. Beramanat atau berpesan adalah menyampaikan amanah. Ibid., h. 67.

${ }^{66}$ Ibid., h. 67.

${ }^{67}$ Departemen Agama, Alquran, h. 928. 


\section{Nilai Musyawarah (Genap Mupakat)}

Nilai musyawarah dalam istilah budaya sumang disebut genap mupakat (musyawarah) termasuk nilai yang amat penting dalam merestorasi karakter masyarakat Gayo. ${ }^{68}$ Sebab apa yang telah dimusyawarahkan harus dipegang teguh dan dilaksanakan secara konsisten (istiqâmah) oleh masyarakat Gayo. Nilai musyawarah sangat penting dalam tukar pikiran, membentuk pendapat dan memberikan solusi terhadap masalah yang dihadapi bersama, terutama dalam membicarakan atau menyelesaikan masalah bersama.

\section{Nilai Tolong-Menolong (Alang Tulung Berat Bantu)}

Dalam sistem budaya sumang ada istilah alang tulung, beret bebantu mengandung prinsip melakukan kegiatan secara bergotong royong. Pengertian daripada alang adalah rebah (tidur), ku alangan mulo ku umah rinung so (ku tidurkan saja diriku ke kamar itu). ${ }^{69} \mathrm{Jadi}$, alang adalah apabila ada suatu pekerjaan yang sangat berat, dikerjakan bersama-sama, sehingga beban yang berat tadi terasa ringan dan mudah. Sedangkan pengertian tulung (tolong) adalah mengharapkan bantuan orang lain, sehingga beban berat terasa ringan, misalnya anak oya ne nge nguk kin tulung (anak itu sudah dapat meringankan beban), dan muniro tulung (meminta bantuan). ${ }^{70}$ Jadi, alang tulung berat bebantu adalah tolong menolong dalam pekerjaan berat, sehingga terasa ringan dilakukan.

\section{Bahaya dan Sanksi Bagi Pelanggar Budaya Sumang}

Bagi para pelanggar sumang dapat menimbulkan bahaya yang bukan hanya menimpa dirinya sendiri, tetapi juga bagi orang lain, keluarga, saudara, dan masyarakat. ${ }^{71}$ Misalnya berbuat zina menghilangkan harga diri pelakunya dan merusak masa depannya, membebani kehinaan yang berkepanjangan kepada pezina dan kepada keluarganya. Bahkan bahaya zina adalah dosa dan keburukan. Perbuatan zina dilarang Allah sesuai Firman-Nya, "dan janganlah kamu mendekati zina; Sesungguhnya zina itu adalah suatu perbuatan keji dan jalan yang buruk. (Q.S. al-Isrâ'/17: 32). ${ }^{72}$

Semua bentuk budaya sumang Gayo memiliki dampaknegatif dan positif yang ditimbulkan

\footnotetext{
${ }^{68}$ Wawancara dengan Ibu Raidani, Guru Muatan Lokal Pendidikan Sumang MTsN Pegasing Kabupaten Aceh Tengah pada Hari Selasa 04 Juli 2017 di Takengon.

${ }^{69}$ M.J. Melalatoa, Kamus Bahasa Gayo-Indonesia (Jakarta: Pusat Pembinaan dan Pengembangan Bahasa, Departemen Pendidikan dan Kebudayaan, 1985), h. 4.

${ }^{70}$ Ibid., h. 34.

${ }^{71}$ Perzinaan juga membunuh masyarakat dari segi kemudahan melampiaskan nafsu sehingga kehidupan rumah tangga menjadi sangat rapuh, bahkan tidak dibutuhkan lagi. Keluarga menjadi sangat rapuh padahal ia merupakan wadah yang terbaik untuk mendidik dan mempersiapkan generasi muda memikul tanggung jawabnya. M. Quraish Shihab, Tafsir al-Misbah, Vol. 7 (Jakarta: Lentera Hati, 2009), h. 79-80.

${ }^{72}$ Departemen Agama RI, Alquran, h. 429.
} 
oleh pelakuknya. Bahaya negatifnya pelakunya bisa berbuat jahat, keji, munkar, berzina, berdusta, berbohong, mengumpat, mengintip, mendengar bisik-bisikan yang mengandung nafsu birahi, bersenda gurau dan berbuat yang dilarang adat. Dampak positifnya, seperti perbuatan baik, beramal saleh, berakhlak mulia, jujur, berkata sopan, lembah lembut, waspada, menjaga diri dari dosa, maksiat,dan mungkar serta bergaul secara patut dan wajar. Sanksi atau hukuman bagi para pelaku pelanggar sumang atau edet sumang gere igenapi (adat sumang tidak dipenuhi), maka pelakunya diberikan sanksi benci resam (dikucilkan) dari masyarakat. Bahkan dihukum parak ${ }^{73}$ (tidak diakui sebagai warga masyarakat). Sanksi sumang ini sesuai dengan hadis Rasulullah Saw., sebagai berikut, "berkata Abu Said sesungguhnya ini adalah ketentuan sebagaimana saya mendengar Nabi SAW. bersabda "siapa di antara kamu yang melihat suatu kemungkaran, maka hendaklah ia mengubahnya dengan tangannya, jika tidak mampu, maka dengan lisannya, dan jika tidak mampu juga maka dengan hatinya, maka yang demikian itu selemah-lemah iman (H.R. Muslim). ${ }^{74}$

\section{Kesimpulan dan Saran}

Masyarakat Gayo di Aceh memiliki aturan-aturan tentang berbagai aspek hidup dan kehidupan yang tumbuh, berkembang, dan dilestarikan dari usaha para pendahulu leluhur suku ini. Aturan itu disebut edet (adat). Dalam praktiknya adat mengandung makna yang luas, mencakup semua hal dimana mayarakat Gayo menjadi terbiasa untuk melakukannya. Di antara adat yang harus dibiasakan dan dilakukan oleh masyarakat Gayo dari generasi ke generasi adalah adat sumang, atau budaya sumang. Budaya ini masih tetap berlaku sebagai bentuk peraturan pergaulan dalammasyarakat Gayo, yaitu larangan dalam pergaulan bebas pria dan wanita yang bukan mahramyang menjurus kepada perbuatan dosa, maksiat, keji, dan munkar meliputi tindak kekerasan, seperti perzinaan, pemerkosaan, penyalah-gunaan obat narkotika, narkoba, perampokan, perjudian, bunuh diri, dan gangguan jiwa lainnya.

Implementasi budaya sumang ini sangat relevan dalam upaya merestorasi karakter masyarakat Gayo, karena merupakan tradisi dan sarana yang dapat mengantarkan masyarakat Gayo menjadi berkarakter mulia. Restorasi adalah upaya memperbaiki, mengembalikan, memulihkan, dan mencerahkan kembali sebagian masyarakat Gayo yang tidak berkarakter menjadi berkarakter mulia, dari yang tidak terpuji menjadi terpuji, dari yang tidak memiliki rasa malu (gere mukemel) menjadi memiliki rasa malu (mukemel). Karena lahirnya budaya sumang ini adalah benteng yang kokoh, tameng yang kuat dan handal dalam menghadapi budaya asing yang tidak sesuai dengan budaya masyarakat Gayodi Aceh yang otentik, orisinal, dan adiluhung.

${ }^{73}$ Hukuman parak adalah sanksi adat yang tereberat yang dinamakan Jeret Naru (Kuburan Panjang) Lihat, Himpunan Qanun, h. 143.

${ }^{74}$ Dapat merujuk kepada salah satu hadis Nabi SAW., Riwayat Imam Muslim, Shâh $\underline{h} \underline{h}$ Muslim, Juz I (Beirut: Dâr al-Fikr, 1992), h. 50. 
Karenaitu, semua pihak, baik individu, remaja, pemuda, mahasiswa, orang tua, masyarakat, tokoh adat, agama, ulama, cendekiawan, dan pemerintah daerah harus kerjasama untuk menjaga, memelihara, melestarikan dan mengimplementasikan budaya sumang ini, agar harga diri, harkat dan martabat keluarga dan masyarakat tetap terpelihara dari perbuatan amoral yang dilarang ajaran Islam dan adat Gayo. Kepada pemerintah daerah diharapkan membuat desa binaan untuk menerapkan danmembumikan nilai-nilai budaya sumang agar tetap lestari sepanjang masa dan tidak pudar serta hilang tergilas oleh arus negatif globalisasi dan modernisasi bangsa.

\section{Pustaka Acuan}

Abbas, Syahrizal. Hukum Adat dan Hukum Islam di Indonesia: Refleksi terhadap Beberapa Bentuk Integrasi Hukum dalam Bidang Kewarisan di Aceh. Yogyakarta: Yayasan Nadia, 2004.

Abdullah, M. Amin. Falsafah Kalam di Era Post Modernisme. Yogyakarta: Pustaka Pelajar, 1995.

Abubakar, al-Yasa. Penerapan Syariat Islam di Aceh: Upaya Penyusunan Fiqih dalam Negara Bangsa. Banda Aceh: Dinas Syariat Islam NAD, 2008.

Ali, Abdurrahim. "Peranan Islam Melalui Adat Gayo dalam Pembangunan Mayarakat Gayo," Makalah Seminar Ilmu Pengetahuan dan Kebudayaan, pada tanggal: 20-24 Januari 2006 di Takengon.

Baihaqi, A.K. Mendidik Anak dalam Kandungan Menurut Ajaran Pedagogis Islam. Jakarta: Darul Ulum Press, 2003.

Bowen, John R. Muslim Trough Discourse: Religion and Ritual in Gayo Society. Princeton, New Jersey: University Press, 1991.

Bowen, John.R. Sumatran Politics and Poetics, Gayo History, 1900-1989. New Haven and London: Yale University Press, 1991.

Harahap, Syahrin. "Guru di Tengah Restorasi Karakter Bangsa," Makalah Seminar Nasional Tenaga Kependidikan dan Pembangunan Karakter Bangsa STAI al-Hikmah Medan, 4 April 2012.

Hawari, Dadang. Al-Qur'an, Ilmu Kedoktoren Jiwa dan Kesehatan Jiwa. Jakarta: Dana Bhakti Prima Yasa, 1998.

Himpunan Qanun Kabupaten Aceh Tengah. Takengon: Sekretariat Daerah Kabupaten Aceh Tengah, 2002.

Hurgronje, C. Snouck. Gayo: Masyarakat dan Kebudayaan Awal Abad ke-20, terj. Hatta Hasan Aman Asnah. Jakarta: Balai Pustaka, 1996.

Al-Jauziyyah, Ibnu Qayyim. Taman Orang-Orang Jatuh Cinta dan Memendam Rindu, terj. Kathur Suhardi. Bekasi: Dar al-Falah, 2012.

Mahmud, Ibrahim. "Peranan Islam Melalui Adat Gayo dalam Pembangunan Masyarakat 
Gayo," Makalah Seminar Ilmu Pengetahuan dan Kebudayaan Tanggal 20-24 Januari 1986 di Takengon.

Ibrahim, Mahmud. Syariat dan Adat Istiadat. Takengon: Yayasan Maqamam Mahmuda, 2002.

Ibrahim, M. Yacob. "Sejarah Adat Istiadat dan Kebudayaan Gayo," Majalah Telangke, Edisi: 5 Tahun 1/1996. Medan: KGAT Medan, 1996.

Jindan, Khalid Ibrahim. Teori Politik Islam: Telaah Kritis Ibn Taimiyah Tentang Pemerintahan Islam, terj. Masrohim. Surabaya: Risalah Gusti, 1995.

Kartanegara, Mulyadhi. Menyelami Lubuk Tasawuf. Jakarta: Erlangga, 2006.

Mashad, Dhurorudin. Akar Konflik Politik Islam di Indonesia. Jakarta: Pustaka al-Kautsar, 2008.

Melalatoa, M.J. Kamus Bahasa Gayo-Indonesia. Jakarta: Pusat Pembinaan dan Pengembangan Bahasa, Departemen Pendidikan dan Kebudayaan, 1985.

Melalatoa, M.J. “Budaya Malu: Sistem Budaya Gayo," dalam Sistem Budaya Indonesia, Jakarta: Fakultas Sosial dan Ilmu Politik Universitas Indonesia dan Pelajar-Jakarta, 1997.

Pinan, A.R. Hakim Aman, "Budaya Sumang yang Menjadi Sumbang," Majalah Telangke, Nomor: 5 Tahun 1/1996, Medan: Keluarga Gayo Aceh Tengah KGAT, 1996.

Pinan, A.R. Hakim Aman. Daur Hidup Gayo, Arahan Adat Kelahiran, Khitan, Pendidikan, Perkawinan. Medan: ICMI Orsat Aceh Tengah-Prima Utama, 1998.

Prayitno, \& Afriva Khaidir. Model Pendidikan Karakter-Cerdas. Padang: Universitas Negeri Padang, 2010.

Prayitno, \& Afriva Khaidir. Pendidikan Karakter dalam Pembangunan Bangsa. Jakarta: Gramedia Widiasarana Indonesia, 2011.

Shaliba, Jamil. al-Mu'jam al-Falsafi, Juz I. Mesir: Dâr al-Kitâb al-Mishri, 1978.

Syahnan, Mhd. dan Saleh Partaonan Daulay. "Reconsidering the Convergence of the Philosophy of Islamic Law with Other Scinces," dalam Indo-Islamica: Journal of Islamic Science, Vol. 3, No. 1 (2006).

Syukri. Sarakopat: Sistim Pemerintahan Tanah Gayo dan Relevansinya terhadap Pelaksanaan Otonomi Daerah. Jakarta: Hijri Pustaka Utama, 2006.

Syukri. Ulama Membangun Aceh: Kajian Tentang Pemikiran, Peran Strategis, Kiprah, Ulama dalam Kelangsungan Pembangunan dan Pengembangan Syariat Islam di Aceh. Medan: IAIN Sumatera Utara, 2012. 